\title{
PEMANFAATAN LIMBAH PRODUKSI MIE SEBAGAI ALTERNATIF PAKAN TERNAK
}

\author{
Susi Agung Purwaningtyas ${ }^{1, a)}$, Sulhadi ${ }^{2, b)}$, Teguh Darsono ${ }^{\text {c) }}$, \\ Aninditya Dwi Perwitasari \\ 1) Program studi Magister Pendidikan Fisika, Pascasarjana, \\ Universitas Negeri Semarang \\ Jl. Kelud Utara III, Kota Semarang 50237
}

E-mail : a)ardifendy@gmail.com, b)sulhadipati@yahoo.com, c)teguh_darsono@yahoo.com

\begin{abstract}
One of the alternative utilization of wasted noodle production is to overcome the problem of limited amount of forage forage especially in the dry season. The purpose of this study to determine the nutrition of noodle wasted noodle production as an alternative to cattle feed. Before the nutrition testing, first the wasted noodle production enriched content. Noodle production waste is mixed with grass, rice bran, and straw. These materials are the usual feed ingredients given to cows and have been tested for their nutritional content. Rasum I obtained nutrient content: $28 \%$ crude fiber, $0.5 \%$ fine protein, $29 \%$ fat. Ration II of nutrition contained: crude fiber $24.6 \%, 0.5 \%$ fine protein, $25.6 \%$ fat. Ration III of nutrition contained: crude fiber $19.4 \%$, protein $0.5 \%$, fat 19.9
\end{abstract}

Keyword: Wasted noodles production, animal food

\section{PENDAHULUAN}

Usaha ternak sapi merupakan salah satu usaha yang banyak dilakukan oleh masyarakat Indonesia. Sukses atau tidaknya dalam menjalani ternak sapi ditentukan oleh banyak faktor. Pakan merupakan salah satu faktor utama yang menentukan keberhasilan suatu usaha ternak, karena $60-70$ $\%$ biaya digunakan untuk kebutuhan pakan [1]. Hijauan merupakan pakan yang paling baik untuk ternak sapi karena selain merupakan bahan alami hijauan juga memiliki kadar serat kasar yang tinggi [2]. Sapi merupakan hewan yang pada dasarnya memamabiak sehingga memerlukan pakan yang memiliki kadar serat kasar yang tinggi.

Indonesia merupakan negara yang memiliki 2 musim, penghujan dan kemarau. Saat musim penghujan, tanaman hijau akan tumbuh dengan suburnya. Pakan untuk ternak akan dengan mudah di dapatkan. Namun lain halnya ketika musim kemarau datang, peternak harus pandai dalam hal mengatur pakan dari tanaman hijau agar pakan tidak habis terlebih dahulu sebelum musim kemarau berakhir. Saat musim kemarau penggunaan pakan unggas harus diatur seefisien mungkin. Ketersediaan pakan hijau yang terbatas pada musim kemarau tersebut dapat disiasati dengan pembuatan ransum. Peternak harus mampu memanfaatkan ketersediaan bahan pakan yang ada tanpa mengabaikan segi kualitas bahan pakan tersebut. Pemilihan bahan pakan yang tepat sebagai campuran maupun tambahan dalam pakan sangat berperan penting. Pembuatan ransum atau campuran dari berbagai jenis bahan pakan dapat memanfaatkan limbah sebagai upaya untuk penghematan pakan hijauan saat musim kemarau.

Limbah produksi mie merupakan limbah produksi dalam bentuk padatan yang berupa sisa rontokan dari proses pembuatan mie sebelum dikemas [2]. Limbah mie memiliki kandungan gizi yang cukup tinggi untuk dapat dimanfaatkan sebagai campuran pakan ternak dan dapat membantu 
mengemat kebutuhan pakan dari tanaman hijau khususnya saat musim kemarau. Kandungan protein pada limbah mie memang lebih rendah jika dibandingkan dengan pakan hijau atau dedak yang biasa diberikan pada sapi, namun limbah mie memiliki keunggulan yang lain[3]. Kandungan lemak pada limbah mie tergolong cukup tinggi. Jika ditinjau dari sisi lain, limbah mie memiliki memiliki harga yang relatif murah dan mudah didapatkan sehingga peternak sapi dapat dengan mudah memperoleh limbah mie dan tanpa harus mengeluarkan uang yang begitu banyak.

Berikut disajikan data tentang kandungan gizi yang dimiliki oleh limbah mie.

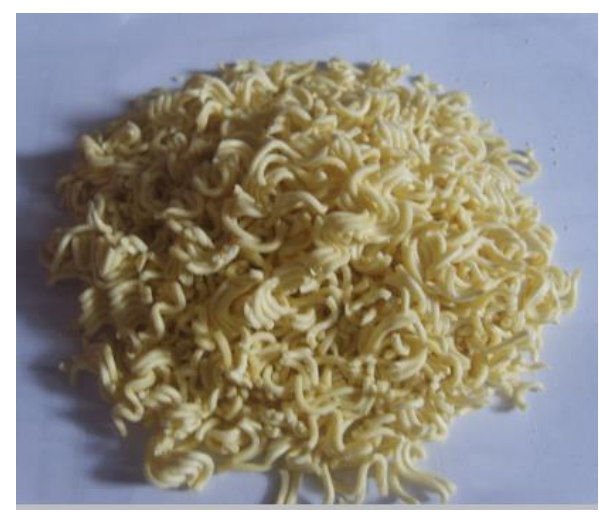

Gambar 1. Limbah Produksi Mie

Tabel 1. Kandungan Gizi Limbah Industri Mie Instant

\begin{tabular}{l|l}
\hline [1] NUTRIEN & [2] LIMBAH MIE (\%) \\
\hline [3] SERAT KASAR & {$[4] 1,37$} \\
[5] LEMAK & {$[6] 8,73$} \\
[7] PROTEIN HALUS & {$[8] 0,6$} \\
\hline
\end{tabular}

Tujuan dari penelitian ini adalah untuk mengetahui kandungan gizi dari bahan bahan pakan yang terdiri dari campuran berbagai macam bahan pakan ditambah dengan limbah produksi mie atau yang disebut dengan ransum.

\section{METODE PENELITIAN}

Penelitian ini dilaksanakan di laboratorium terpadu untuk pengujian kandungan gizi. Bahan pakan yang tersedia seperti rumput hijau, dedak padi, jerami padi, dan limbah produksi mie di haluskan dengan proses ball mill.

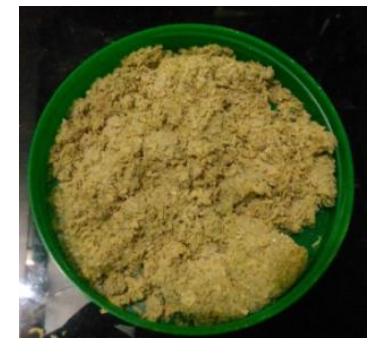

Gambar 2. Dedak Padi 


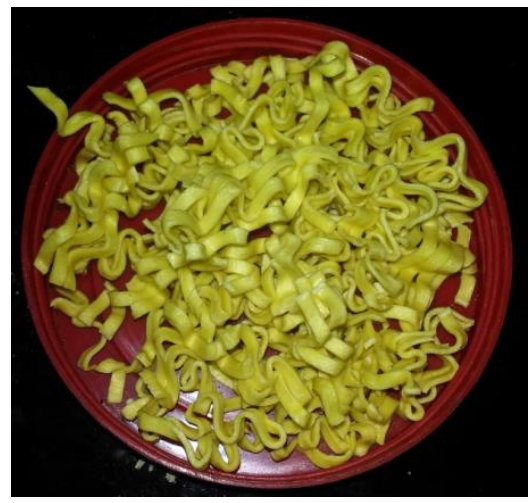

Gambar 3. Limbah Produksi Mie

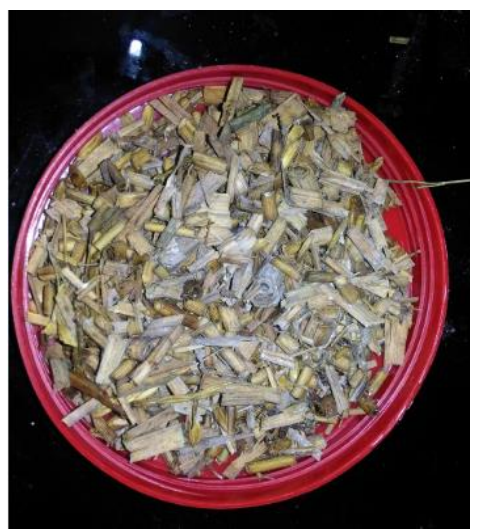

Gambar 4. Jerami Padi

Bahan pakan yang tersedia kemudian dicampur sehingga menjadi ransum dengan komposisi yang berbeda. Tujuan penelitian ini adalah untuk mengetahui kandungan gizi pakan sapi yang dicampur dengan limbah produksi mie. Penambahan limbah mie difungsikan sebagai alternatif pakan ternak dengan kandungan gizi yang tetap memadai saat musim kemarau pada saat sediaan hijauan sangat minim. Data kandungan gizi pada alternatif pakan ternak yang didapat kemudian dianalisis dengan cara di bandingkan dengan kandungan gizi pada pakan ternak yang sudah biasa diberikan kepada ternak sapi, yakni berupa pakan hijauan, dedak padi, dan jerami .

Kandungan gizi yang akan dianalisis antara lain serat kasar, protein, dan lemak. Protein dalam pakan sapi merupakan salah satu zat yang penting karena protein merupakan komponen utama organ tubuh, enzim, dan zat pengatur hormon [3]. Lemak memiliki peranan penting bagi baik bagi pertumbuhan maupun perkembangan sapi, sebab lemak dapat berfungsi sebagai cadangan sumber energi bagi ternak peliharaan.

\section{HASIL DAN PEMBAHASAN}

Penelitian ini menggunakan variasi sample yang kemudian diuji kandungannya dengan tujuan untuk mengetahui kandungan gizi yang terdapat pada ransum yang dicampur dengan limbah produksi mie yang telah dibuat dengan komposisi tertentu.

Tabel 3. Kandungan Gizi Jerami Padi

\begin{tabular}{ll|ll}
\hline [9] NUTRIEN & {$[10]$} & JERAMI PADI (\%) \\
\hline$[11]$ & SERAT KASAR & {$[12]$} & 34,2 \\
{$[13]$} & LEMAK & {$[14]$} & 1,55 \\
{$[15]$} & PROTEIN KASAR & {$[16]$} & 5,0 \\
\hline
\end{tabular}


Jerami padi merupakan pakan sapi yang kualitasnya paling rendah karena memiliki daya cerna yang rendah [4]. Kendati demikian jerami padi memiliki kandungan protein kasar sebesar 5\% yang mana protein juga merupakan zat yang tidak kalah pentingnya dibutuhkan oleh sapi sehingga jerami padi sering digunakan para peternak untuk bahan campuran pada pakan ternak.

Tabel 4. Kandungan Dedak Padi

\begin{tabular}{llll}
\hline$[17]$ & NUTRIEN & {$[18]$} & DEDAK PADI (\%) \\
\hline$[19]$ & SERAT KASAR & {$[20]$} & 35,3 \\
\hline$[21]$ & LEMAK & {$[22]$} & 3,2 \\
\hline$[23]$ & PROTEIN HALUS & {$[24]$} & 6,5 \\
\hline
\end{tabular}

Dedak padi merupakan pakan non hijauan yang memiliki daya cerna cukup baik menurut Badan Litbang Pertanian Yogyakarta. Para peternak banyak memilih dedak padi sebagai campuran untuk memperkaya kandungan pada pakan ternak sapi.

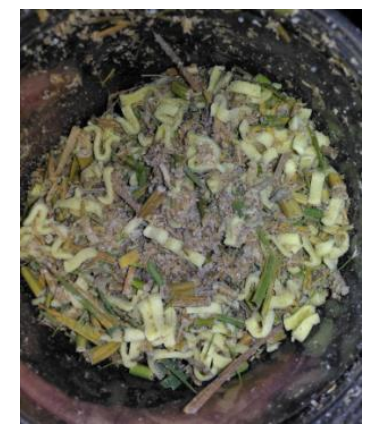

Gambar 5. Ransum

Tabel 5. Kandungan Gizi Ransum I (rumput, dedak padi, dan jerami)

\begin{tabular}{ll|ll}
\hline$[25]$ & NUTRIEN & {$[26]$} & RANSUM I (\%) \\
\hline$[27]$ & SERAT KASAR & {$[28]$} & 28 \\
{$[29]$} & LEMAK & {$[30]$} & 29 \\
{$[31]$} & PROTEIN HALUS & {$[32]$} & 0,5 \\
\hline
\end{tabular}

Pada ransum I bahan pakan yang dicampurkan merupakan golongan limbah pertanian. Pada tabel disajikan data kandungan gizi yang berupa serat kasar sebesar $28 \%$, lemak $29 \%$, dan protein halus $0,5 \%$. Hasil uji kandungan laboratorium menunjukan bahwa kandungan gizi pada ransum I yang berupa campuran limbah pertanian cukup memenuhi kebutuhan nutrisi sapi.

Tabel 6. Kandungan Gizi Ransum II (40\% rumput $+30 \%$ dedak padi $+10 \%$ jerami $+20 \%$ limbah produksi mie)

\begin{tabular}{ll|ll}
\hline$[33]$ & NUTRIEN & {$[34]$} & RANSUM II (\%) \\
\hline$[35]$ & SERAT KASAR & {$[36]$} & 24,6 \\
{$[37]$} & LEMAK & {$[38]$} & 19,9 \\
{$[39]$} & PROTEIN HALUS & {$[40]$} & 0,5 \\
\hline
\end{tabular}

Pada ransum II terlihat kandungan proteinnya sangat rendah bahkan kurang dari $1 \%$ hal ini dikarenakan kandungan protein yang teruji merupakan jenis protein halus. Pada tabel terlihat kandungan lemak pada ransum II cukup tinggi yakni 19,9\%. Limbah produksi mie diberikan kadar $20 \%$ 
Tabel 7. Kandungan Gizi Ransum III (30\% rumput $+20 \%$ dedak padi $+10 \%$ jerami $+40 \%$ limbah produksi mie)

\begin{tabular}{ll|ll}
\hline$[41]$ & NUTRIEN & {$[42]$} & RANSUM III (\%) \\
\hline$[43]$ & SERAT KASAR & {$[44]$} & 19,4 \\
{$[45]$} & LEMAK & {$[46]$} & 25,6 \\
{$[47]$} & PROTEIN HALUS & {$[48]$} & 0,5 \\
\hline
\end{tabular}

Pada ransum III terlihat kandungan proteinnya sangat rendah bahkan kurang dari $1 \%$ hal ini dikarenakan kandungan protein yang teruji merupakan jenis protein halus sama halnya dengan kandunan pada ransum II. Pada tabel terlihat kandungan lemak pada ransum III cukup tinggi yakni 25,6\%. Kadar lemak pada ransum III ini mengalami kenaikan jika dibandingkan dengan Ransum II. Limbah produksi mie diberikan kadar $40 \%$

Limbah pertanian seperti jerami padi dan dedak padi memang sudah lama dimanfaatkan para petani untuk membuat ransum. Selain untuk menghemat hijauan saat musim kemarau, kandungan gizi pada kedua limbah pertanian itupun sudah teruji. Limbah produksi mie bukan termasuk limbah pertanian namun jika kita perhatikan pada tabel 1 kandungan gizi pada limbah mie tergolong cukup tinggi untuk pemenuhan gizi ternah sapi. Pengujian hasil laboratorium pada limbah produksi mie yang dicampurkan ke dalam pakan ternak menunjukkan hasil yang positif. Jika ditinjau dari kandungan lemaknya pada kadar 20\% pencampuran limbah produksi mie menunjukkan hasil 19,9\% terdapat kandungan lemak pada ransum tersebut. Pada kadar $40 \%$ pencampuran limbah produksi mie menunjukkan hasil 25,6\% terdapat kandungan lemak. Terlihat kandungan lemak terjadi peningkatan saat kadar pencampuran limbah produksi mie ditambah pada campuran bahan pakan untuk ternak. Hal ini menunjukkan bahwa limbah produksi mie walaupun bukan termasuk limbah pertanian yang merupakan bahan alami ternyata juga dapat menjadi alternatif pakan ternak yang kandungannya diperkaya dengan bahan alami yang sudah biasa diberikan kepada sapi. Kandungan lemak pada limbah produksi mie memang tergolong tinggi, namun limbah produksi mie mengandung nutrien yang tidak seimbang dan juga antinutrisi berupa arabinoxylan [5] sehingga memungkingkan pakan yang dikonsumsi tidak mampu dicerna dan dimanfaatkan tubuh sapi dengan baik. Sehingga walaupun hasil pengujian laboratorium menunjukkan terjadi peningkatan kadar lemak ketika kadar kadar limbah produksi mie ditambah bukan berarti semakin banyak kadar limbah produksi mie semakin baik. Penggunaan limbah produksi mie hanya sebesar 20\% dapat ditambahkan pada pakan ternak [6]

\section{SIMPULAN}

Berdasarkan hasil penelitian maka dapat disimpulkan bahwa limbah produksi mie dapat dimanfaatkan sebagai alternatif pakan ternak yang kandungannya diperkaya dengan pencampuran bahan pakan hijau dan limbah pertanian yang biasa diberikan kepada sapi.

\section{UCAPAN TERIMAKASIH}

Terimakasih kepada Kepala Laboratorium Terpadu yang telah memberikan sarana dan prasarana untuk mendukung kegiatan penelitian ini serta kepada semua pihak yang telah membantu dalam kegiatan penelitian.

\section{REFERENSI}

[1] Wahju, J. 2004. Ilmu Nutrisi Unggas. Gadjah Mada University Press. Yogyakarta.

[2] Agustin, M. 2008. Pengaruh Penggunaan Limbah Mie Dalam Pakan Terhadap Penampilan Produksi Ayam Pedaging. Skripsi. Jurusan Nutrisi dan Makanan Ternak. Fakultas Peternakan. Universitas Brawijaya. Malang. 
[3] Djaenudin., Efendi., M. Efendi., I. Hernaman dan I. P. Putut. 2005. Pengaruh Penggunaan Limbah Mie Dalam Ransum Terhadap Kinerja Ayam Pedaging. Lembaga Ilmu Pengetahuan Indonesia. Universitas Padjajaran. Bandung.

[4] Hamdan, A., N. Ngadiyono dan A. Agus. 2004. Konsumsi pakan dan pertambahan bobot badan sapi Bali dan sapi PO jantan yang diberi pakan basal jerami padi dan suplemen konsentrat. Jurnal Pengembangan Peternakan Tropis, Special Edition, Oktober 2004. Buku 2. Hal:126-131.

[5] Rizal, Y. 2006. Ilmu Nutrisi Unggas. Andalas University Press. Padang.

[6] Widodo, E. 2003. Manfaat Diet Pada PenaggulanganHiperkolesterolemi.www.USU.ac.id. diakses tanggal 8 Mei 2017. 